Relations industrielles

Industrial Relations

\title{
Appelbaum, Eileen, and Rosemary Batt, The New American Workplace: Transforming Work Systems in the United States
}

Paula B. Voos

Volume 50, numéro 1, 1995

URI : https://id.erudit.org/iderudit/050999ar

DOI : https://doi.org/10.7202/050999ar

Aller au sommaire du numéro

Éditeur(s)

Département des relations industrielles de l'Université Laval

ISSN

0034-379X (imprimé)

1703-8138 (numérique)

Découvrir la revue

Citer ce compte rendu

Voos, P. B. (1995). Compte rendu de [Appelbaum, Eileen, and Rosemary Batt, The New American Workplace: Transforming Work Systems in the United States]. Relations industrielles / Industrial Relations, 50(1), 225-226.

https://doi.org/10.7202/050999ar

Tous droits réservés @ Département des relations industrielles de l'Université Laval, 1995
Ce document est protégé par la loi sur le droit d'auteur. L’utilisation des services d'Érudit (y compris la reproduction) est assujettie à sa politique d'utilisation que vous pouvez consulter en ligne.

https://apropos.erudit.org/fr/usagers/politique-dutilisation/ 


\section{Recensions}

\section{Book Reviews}

\section{The New American Workplace: Transforming Work Systems in the United States}

by Eileen APPELBAUM and Rosemary BATT, Ithaca, New York, ILR Press, 1994, 287 p., ISBN 0-87546-318-5 (acid free paper), ISBN 0-87546-319-3 (pbk.).

Eileen Appelbaum and Rosemary Batt undertake a formidable task in The New American Workplace. In order to assess the contemporary movement to transform work in the U.S., they synthesize the results of more than 175 case studies of workplace innovation and 12 quantitative surveys of changing work practices. They are careful to differentiate between divergent models of workplace reform, reviewing diverse foreign approaches before considering emergent U.S. initiatives. Appelbaum and Batt evaluate current impediments to change. They then consider how public policies could be altered to be more supportive of team production and other promising vehicles of enhanced productivity and employee voice. Overall, they succeed brilliantly in all these goals. This volume is an excellent compendium of the current state of work reorganization. However, it is more than a compendium. It advances a new theoretical vision of what is happening in the American workplace. It deserves to shape the thinking of academics, practitioners, and public policy makers with regard to removing barriers to high performance work systems.

Theoretically, Appelbaum and Batt begin by reviewing several influential foreign, or early U.S., approaches to workplace change: Swedish sociotechnical systems, Japanese lean production, Italian flexible specialization, German diver- sified quality production, and the older American HR model. This portion of the book has been very useful to me in teaching graduate courses in industrial relations. The authors' distinct delineation of the similarities and differences between all these models is extremely helpful for advancing thinking in an area that has all too often lumped together quite distinct approaches to work reorganization. Then, Appelbaum and Batt discuss what they regard as the two emerging models of work reform in the U.S. today: American lean production and American team production. The recognition that currently there are two distinctly different constellations of workplace reform is ground-breaking. It not only has profoundly influenced my own thinking but also it deserves wide dissemination and scrutiny.

Appelbaum and Batt point out that American team production takes a decentralized approach to high performance. It emphasizes collaborative labormanagement structures that increase worker participation in a host of firm decisions. It tends to result in the reduction of managerial jobs and the transfer of decision-making to the work group. American lean production, on the other hand, is more centralized in its approach. It emphasizes particular elements of TQM: process management, re-engineering of work flows, data collection and performance measurement, and a 
centralized "alignment of vision" between the company and its employees. Work standardization and simplification in order to increase quality (as opposed to job rotation, enrichment, and/or enlargement) and more quality managers are often on the lean production agenda. Team production and lean production both can exist in either union or nonunion settings, but the best-practice cases of team production seem to be found in organized workplaces. Lean production's best-practice exemplars are more likely to be nonunion companies.

Both models seem to result in significant improvements in efficiency and quality, at least with good implementation. Both systems seem to work equally well with regard to improving firm performance, although it may well be that one system works better in particular circumstances than others. In particular, in environments where more flexibility or creativity is necessary, team production may have the edge. In more stable environments, lean production may yield greater performance gains. On the other hand, the two systems are not equal with regard to outcomes important to employees. Team production clearly gives workers more voice, along with more interesting and varied jobs, more job security, and often more ancillary rights. Lean production may be better for managers. Appelbaum and Batt conclude that public policy should not be neutral between the two types of work reform, but should consider goals important to workers as well as goals important to firms: wage growth, employment security, due process guarantees, job variety, the opportunity to make decisions, and genuine worker voice. I would concur.

Moreover, it is not surprising to me that union firms provide the best exemplars of team production. As I have argued elsewhere, unions give employees the individual security that is neces- sary for effective participation, legitimate change for an often-skeptical workforce, and provide a vehicle whereby employees can share in the overall management or direction of work reorganization at higher, or strategic, levels of decisionmaking.

Appelbaum and Batt's discussion of the current barriers to workplace change are insightful and their public policy recommendations are worthy of serious consideration. It is difficult to summarize their nuanced, thoughtful, and complex discussion along all dimensions. Most centrally, they argue that the institutional framework of the U.S. - our educational system, managerial labor markets, financial institutions, etc. - all evolved to support the old system of mass production. Short-run profit-maximization within this institutional context may not lead to high performance work organization in the U.S., whereas profit-maximization within a different institutional context might well support work reorganization that benefits workers as well as firms. Public policy might focus on realigning educational and training policy, macroeconomic policy, financial market institutions, employment regulation, and other fundamental institutions, to the goal of supporting employee empowerment in high performance work systems. Moreover, firms following a high performance path may be vulnerable to competition from firms following a lowwage, low-skill path. Hence public policy must enforce minimum labor standards.

In sum, The New American Workplace is too important to ignore. Appelbaum and Batt have produced the latest "must read" for the busy industrial relations academic, practitioner, or policy analyst.

PaUla B. Voos University of Wisconsin 